\title{
RE: Enema-induced severe hyperphosphatemia in children
}

\author{
Michael Caswell
}

Accepted: 6 May 2009 /Published online: 26 May 2009

(C) Springer-Verlag 2009

Dear Editor,

Biebl et al. [1] described, in a 13-year-old patient, serious adverse events after receiving four phosphates enemas within $24 \mathrm{~h}$. The authors fail to note that the dose of sodium phosphates enema given was an extreme overdose. First, the recommended adult dose of sodium phosphates enema is one $133-\mathrm{mL}$ bottle (to deliver a dose of $118 \mathrm{~mL}$ containing $19 \mathrm{~g}$ of monobasic sodium phosphate monohydrate and $7 \mathrm{~g}$ of dibasic sodium phosphate heptahydrate [2]) within $24 \mathrm{~h}$; this patient received four bottles within $24 \mathrm{~h}$. Second, while the patient is an adult by the European Medicines Agency definition (http://www.emea.europa.eu/ htms/human/qrd/docs/qrdterms.pdf, accessed on November $13,2008)$, the patient's diminutive size of $18.2 \mathrm{~kg}$ resulting from Costello's syndrome was indicative that a children's enema would have been much more appropriate. Third, although Biebl et al. [1] described the use of $125-\mathrm{mL}$ Fleet enema bottle, Fleet enema of any size is not marketed in Austria.

Proper dosing and timing instructions for Fleet enema are available on the Fleet Laboratories Web site, www. fleetlabs.com.

\section{References}

1. Biebl A, Grillenberger A, Schmitt K (2008) Enema-induced severe hyperphosphatemia in children. Eur J Pediatr 168:111-112. doi:10.1007/s00431-008-0705-2

2. Murray L (2008) Physician's desk reference, 62nd edn. Thompson, New Jersey, pp 1149-1150

M. Caswell $(\bowtie)$

Clinical Operations and Safety, C.B. Fleet Company, Inc.,

4615 Murray Place,

Lynchburg, VA 24502, USA

e-mail: caswellm@cbfleet.com 